\title{
Chronic Viral Hepatitis in Human Immunodeficiency Virus-infected Patients
}

\author{
Insan Bağıș|klık Yetmezlik Virüsü Enfeksiyonu Olan Hastada Kronik Viral Hepatit
}

\author{
Uluhan SILI, Aysun TEKIN, Volkan KORTEN
}

Marmara University Faculty of Medicine, Department of Infectious Diseases and Clinical Microbiology, Istanbul, Turkey

\begin{abstract}
Infectious diseases physicians taking care of human immunodeficiency virus-infected patients should investigate for the presence of chronic hepatitis caused by hepatitis $B$ and hepatitis $\mathrm{C}$ virus infections. This is important as chronic viral hepatitis progresses more rapidly to end-stage liver disease in human immunodeficiency virus-infected patients. Once diagnosed, there are effective drugs for the treatment chronic viral hepatitis. Tenofovir containing anti-retroviral therapy effectively suppresses hepatitis $\mathrm{B}$ replication. Hepatitis $\mathrm{C}$ cure can be achieved with directly acting antiviral agents. Keywords: Human immunodeficiency virus, chronic hepatitis B, chronic hepatitis C, co-infection
\end{abstract}

OZZ

Insan bağışıklık yetmezlik virüsü ile enfekte hastalarda kronik hepatit B virüsü (HBV) ve hepatit C virüsü (HCV) enfeksiyonları da araştııımalıdır. Bu hastalarda kronik viral hepatitler daha hızlı ilerler ve siroz daha çabuk gelişir. Tanı konulduktan sonra kronik viral hepatitler için etkin tedavi verilebilir. HBV'nin replikasyonunu tenofovir içeren anti-retroviral tedaviler ile baskılamak mümkündür. Doğrudan etkili antiviral ilaçların geliştirilmesiyle HCV enfeksiyonunun sağaltımı mümkün hale gelmiştir.

Anahtar Kelimeler: Insan bağışıklık yetmezlik virüsü, kronik hepatit B, kronik hepatit C, ko-enfeksiyon

Sili U, Tekin A, Korten V. Chronic Viral Hepatitis in Human Immunodeficiency Virus-infected Patients. Viral Hepat J 2016;22:39-42

\section{Introduction}

As hepatitis B virus (HBV) and hepatitis $C$ virus (HCV) are transmitted through contact with infectious blood and body fluids, they should be investigated in patients with human immunodeficiency virus (HIV) infection (1). Diagnosing chronic viral hepatitis in HIV-infected patients is important as progression to end-stage liver disease is more rapid in this patient population. HBV replication can be suppressed with nucleosid(t)e reverse transcriptase inhibitors (NRTIs) within antiretroviral therapy (ART) combinations that inhibit HBV polymerase along with HIV-reverse transcriptase. HCV cure has recently become possible using directacting antiviral (DAA) agents, although there are accessibility issues to these drugs in resource-limited settings.

General recommendations for chronic viral hepatitis patients are also applicable for HIV co-infected patients (2). These patients should be vaccinated for hepatitis A virus (HAV) if determined to be seronegative. Alcohol consumption should be decreased to minimum or ceased, if possible. Lifelong surveillance for hepatocellular carcinoma is recommended for patients with fibrosis even after chronic viral hepatitis is controlled or cured (3).

\section{Epidemiology}

Globally, 5-10\% of patients with HIV are HBsAg (+) (4). Two Turkish HIV cohorts reported hepatitis B surface antigen (HBsAg) prevalence as $6.2 \%$ [59 of 949 patients, ACTHIV-IST cohort, (5)] and $5.7 \%$ (33/574, HIV-TR cohort; Korten V, personal communication). $\mathrm{HBsAg}$ seroprevalence is reported to be $2.5-9 \%$ in the general Turkish population (6).

In developed countries, anti-HCV positivity can be up to $25 \%$ in HIV-infected patients $(7,8)$. ACTHIV-IST and HIV-TR cohorts reported $0.9 \%$ (9 of 949 patients) and 3.3\% (18 of 534 patients) anti-HCV positivity, respectively [(5); Korten $\mathrm{V}$, personal communication). The prevalence of anti-HCV positivity has been reported to be $1-2.2 \%$ in the general Turkish population (6).

The above mentioned cohort studies suggest similar seroprevalence rates for chronic viral hepatitis between the general population and HIV-infected patients in Turkey. In countries where 
higher seroprevalence rates for chronic viral hepatitis among HIVinfected patients are reported, this situation is usually attributed to higher intravenous drug user rates among HIV-infected patients (7). In Turkey, HIV is mainly sexually transmitted and intravenous drug use rates are lower in general as well as in HIV-infected Turkish patients $(9,10)$.

\section{Hepatitis B Virus Infection in Human Immunodeficiency Virus-infected Patients}

Serological status of the patient should be determined by analysis of $\mathrm{HBsAg}$, anti-HBc-immunoglobulin $\mathrm{G}$ (lgG) and anti-HBs, and HBV-unexposed patients should be immunized. HBsAg (+) patients should be evaluated for chronic liver disease by means of biochemical tests (e.g., albumin, the international normalized ratio) and radiological methods (e.g., liver ultrasonography and/ or magnetic resonance imaging) (1). If cirrhosis is suspected, a liver biopsy should be performed. In recent years, non-invasive methods to assess liver fibrosis, such as transient elastography, AST to platelet ratio index, and fibrosis-4 score, have been gaining popularity.

It is important to determine anti-HBc-lgG not to miss HBsAg (-) and anti-HBs (-) occult chronic HBV infection (1). HBV-DNA analysis should be performed in patients with isolated anti-HBCIgG positivity to rule out chronic hepatitis, especially in those with elevated hepatic transaminases.

HBsAg (+) patients should be evaluated for the chronic HBV infection phase they are in (i.e., immune-tolerant, HBeAg-positive chronic hepatitis, inactive chronic hepatitis $\mathrm{B}$, or $\mathrm{HBeAg-negative}$ chronic hepatitis B) and be treated accordingly (11).

Progression of acute HBV infection to chronicity is more common in HIV-infected patients (12). Moreover, HBV/HIV co-infected patients have higher HBV-DNA levels leading to faster fibrosis development (12). Liver-related mortality rate is 17.75 times higher in co-infected patients than in HBV monoinfected patients (13). On the other hand, HBV co-infection does not affect HIV/ acquired immunodeficieny syndrome (AIDS) progression (14)

\section{Treatment of Chronic Hepatitis B Virus in Human Immunodeficiency Virus-infected Patients}

ART is indicated in patients with HIV/HBV co-infection independent of CD4 value (2). The goal is to prevent disease progression due to HBV as well as HIV. The recommended NRTI backbone for HIV treatment involving tenofovir and emtricitabine has dual anti-HBV activity. This is the recommended backbone for ART in co-infected patients (2). If a switch is required to abacavir/lamivudine or zidovudin/lamivudine, anti-HBV activity of lamivudine has to be supported with entecavir if tenofovir cannot be used. This is important as not only high rates of resistance develop with lamivudine mono-therapy, but also a valuable high genetic barrier drug, entecavir, can be lost due to cross-resistance. If a switch to NRTI-free treatment is chosen, suppression of HBV has to be maintained with entecavir or tenofovir as patients with advanced fibrosis can easily be decompensated. Tenofovir alefenamide, which is not yet available in Turkey, is poised to replace tenofovir disoproxil fumarate in the near future. This equally effective but less toxic derivative of tenofovir is probably effective against HBV although studies are lacking at this point (15).
The goal is to achieve a complete virological response, which is defined as undetectable HBV-DNA with a sensitive polymerase chain reaction (PCR) test at 24 to 48 weeks of anti-viral therapy (16). In addition to a complete virologic response, HBsAg loss is also a desirable outcome; however, this serologic response is rare (16).

\section{Hepatitis C Virus Infection in Human Immunodeficiency Virus-infected Patients}

Anti-HCV serological status should be checked in HIV-infected patients (1). In anti-HCV (+) patients, HCV-RNA should be quantified and, if viremia is present, HCV genotype should be determined. In HIV-infected patients with alanine transaminase/aspartate transaminase (ALT/AST) elevations, HCV infection should be ruled out. In patients with unexplained ALT/AST elevations and negative anti-HCV, HCV-RNA should be checked for the possibility of false sero-negativity or recent infection. Patients with $\mathrm{HCV}$ viremia should be evaluated for chronic liver disease with methods described above for HBV.

HCV infection progresses more rapidly to cirrhosis with a relative risk of 2.92 in HIV-infected patients (17). On the contrary, $\mathrm{HCV}$ infection does not seem to affect HIV disease progression (18).

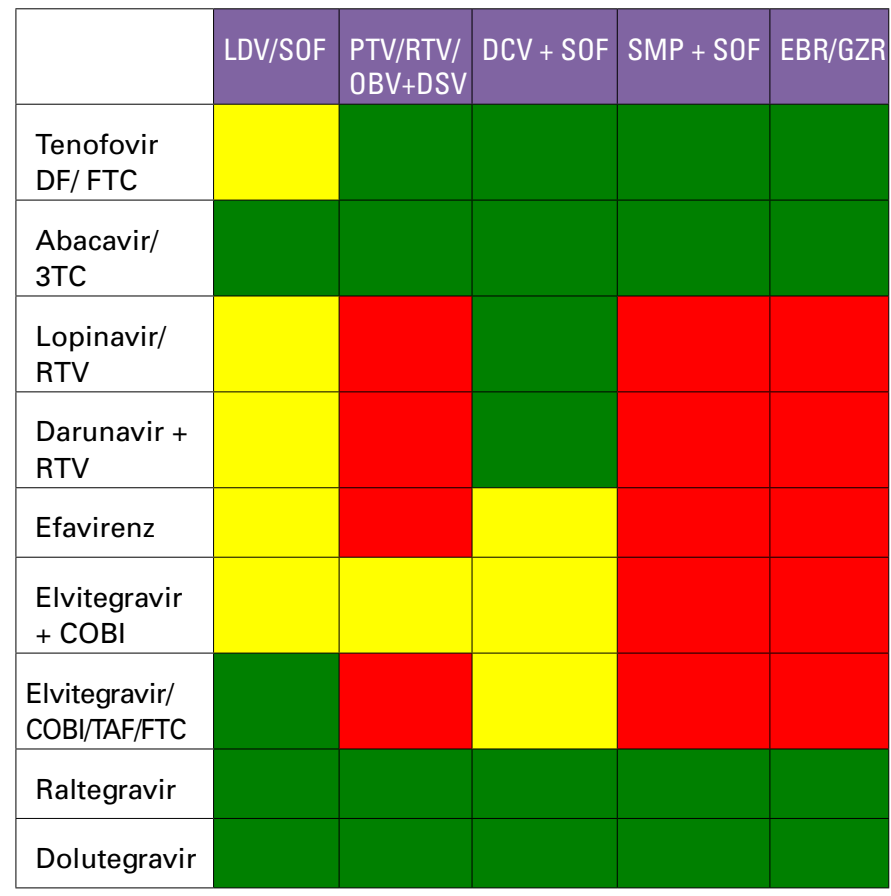

Figure 1. Selected antiretroviral therapy drugs/combinations and their interactions with most current direct-acting antiviral agents (red, co-administration not recommended; yellow, potential interaction that may require monitoring or dose adjustment; green, no significant interaction was observed or expected) [adapted from ref. (15,21)] For most current information, check human immunodeficiency virus drug Interactions website maintained by University of Liverpool- http://www.hiv-druginteractions.org-) 3TC: Lamivudine, COBI: Cobicistat, DCV: Daclatasvir, DF: Disoproxil fumarate, DSV: Dasabuvir, EBR: Elbasvir, EVG: Elvitegravir, FTC: Emtricitabine: GZR: Grazoprevir, LDV: Ledipasvir, OBV: Ombitasvir, PTV: Paritaprevir, RTV: Ritonavir, SMV: Simeprevir, SOF: Sofosbuvir, TAF: Tenofovir alefenamide 


\begin{tabular}{|l|}
\hline Table 1. Points to consider before switching antiretroviral therapy in patients with suppressed human immunodeficiency virus* \\
\hline Review ART history (previous intolerance to ART combinations, virological failure) \\
\hline Review results of previous resistance tests \\
\hline Switch to a new regimen only if virological suppression will be possible \\
\hline Caution while switching from protease inhibitor containing ART regimens when drug resistance is suspected \\
\hline Consult with experts on HIV drug resistance if unsure of which ART combination to choose \\
\hline Check HIV viral load every month for the first three months after the switch \\
\hline Maintain anti-HBV activity in HBV co-infected after the switch \\
\hline $\begin{array}{l}\text { ART: Antiretroviral therapy, HIV: Human immunodeficiency virus, HBV: Hepatitis B virus } \\
\text { *adapted from ref (2). }\end{array}$ \\
\hline
\end{tabular}

\section{Treatment of Chronic Hepatitis C Virus in Human Immunodeficiency Virus-infected Patients}

$\mathrm{HCV}$ co-infection is an indication for ART independent of CD4 levels (2). ART decreases hepatic decompensation risk due to $\mathrm{HCV}$ by $28-41 \%$ (19). However, it is still higher than in HCV monoinfected patients (20). For this reason, HCV should also be treated in HIV-infected patients receiving ART. The goal of HCV therapy is to achieve a sustained virological response (SVR), defined as undetectable HCV-RNA with a sensitive PCR test at least 12 weeks after completion of therapy (21).

$\mathrm{HCV}$ is now a curable disease with the development of DAA agents (22). For a long time, pegylated interferon-alpha and ribavirin were used in patients with HIV with suboptimal response rates (23). Not only this therapy was hard to tolerate due to side effects, but also SVR rates were 15-25\% lower than that in HCV monoinfected patients (24). These agents are no longer recommended for HCV treatment (2). DAAs can cure HCV in HIV-infected patients with response rates similar to that in $\mathrm{HCV}$ mono-infected patients (92-100\% SVR rates) $(15,24)$. However, emerging real-world data suggest lower SVR rates than those reported in clinical trials $(25,26)$. For the most common genotype in Turkey, GT1b, 12 weeks of DAA without ribavirin is recommended for non-cirrhotic patients (21). Unlike mono-infected patients, shorter eight-week treatment is not recommended for HIV/HCV co-infected patients. As HCV treatment field is rapidly evolving, current information should be checked from up-to-date websites, such as http:// hcvguidelines.org. Treatment rules imposed by social security institution of Turkey should be observed for state-insured patients (27).

One question is timing of DAA in patients receiving ART. If DAA is going to be administered with ART, drug-drug interactions and overlapping toxicities should be considered (Figure 1). The most likely three clinical scenarios are presented below:

Scenario 1: Chronic HCV is diagnosed concomitantly with HIV. If there is no urgent need to start ART (i.e., CD4 >500 cells $/ \mathrm{mm}^{3}$, no opportunistic infections, no AIDS-defining illness), DAA could be started before ART with the goal of curing HCV and avoiding any drug-drug interactions. In this case, chosen DAA should not have any anti-HIV activity for example; paritaprevir, ritonavir, ombitasvir, dasabuvir (PrOD) regimen contains ritonavir, which has anti-HIV activity and may select for protease inhibitor resistance if given alone. In cases where ART has to be started immediately (i.e., CD4 $<200$ cells $/ \mathrm{mm}^{3}$ or an AIDS-defining illness is present), the current recommendation is to delay $\mathrm{HCV}$ treatment. In these patients the goal is to start ART, achieve virological suppression, and start immune reconstitution first.

Integrase inhibitors (without the pharmacologic booster) with NRTI backbone are the least likely ART combinations to interact with DAAs (Figure 1). In terms of DAA, daclatasvir/sofosbuvir regimen is the most compatible with different $A R T$ combinations. As ledipasvir increases tenofovir levels, monitoring for tenofovirassociated renal toxicity is recommended if tenofovir and ledipasvir are co-administered (21).

Scenario 2: HIV/HCV co-infected patients stable on ART and now eligible for HCV treatment with newly available DAAs. ART cessation is not recommended to start DAA. However, drug-drug interactions and overlapping toxicities may dictate ART switch. The foremost principle of regimen switch is to maintain viral suppression without compromising future treatment options (2). Points to consider before ART switch are summarized in Table 1.

Scenario 3: HIV patient on ART developing acute HCV. The most recent European AIDS Clinical Society guideline recommends treatment of acute HCV with pegylated interferon and ribavirin if spontaneous resolution does not happen within one to three months, as response to treatment declines with prolonged wait (1). However, as new DAAs are effective in curing chronic HCV with almost $100 \%$ success rate, one can easily wait for up to one year and treat if spontaneous resolution does not take place within that time frame (21). Current treatment rules imposed by social security institution of Turkey allows six months of treatment with pegylated interferon-alpha for patients with acute HCV infection (27).

\section{Conclusions}

Chronic HBV and HCV have to be diagnosed and treated, as liver disease progresses more rapidly in HIV-infected patients. For HIV/HBV-infected patients, tenofovir/emtricitabine backbone is ideal. During ART switches, suppression of HBV replication has to be maintained to avoid flare or decompensation risk. HCV can be cured using DAAs in HIV-infected patients at rates similar to those in $\mathrm{HCV}$ mono-infected patients. The main issue other than availability and cost of these drugs is to watch for drug-drug interactions and overlapping toxicities between DAAs and ART. Integrase inhibitors as a part of ART seem to have the least potential to interact with other drugs. Further liver injury should be prevented by vaccination or abstinence and hepatocellular carcinoma surveillance should be employed for patients at risk. 


\section{Ethics}

Peer-review: External and Internal peer-reviewed.

\section{Authorship Contributions}

Surgical and Medical Practices: Uluhan Sili, Concept: Uluhan Sili, Design: Uluhan Sili, Data Collection or Processing: Uluhan Sili, Aysun Tekin, Analysis or Interpretation: Uluhan Sili, Volkan Korten, Literature Search: Uluhan Sili, Aysun Tekin, Writing: Uluhan Sili.

Conflict of Interest: No conflict of interest was declared by the authors.

Financial Disclosure: The authors declared that this study has received no financial support.

\section{References}

1. EACS. European Guidelines for treatment of HIV-positive adults. October 2015; Available from: http://www.eacsociety. org/guidelines/eacs-guidelines/eacs-guidelines.html.

2. Panel on Antiretroviral Guidelines for Adults and Adolescents. Guidelines for the use of antiretroviral agents in HIV-1-infected adults and adolescents. January 28, 2016; Available from: https://aidsinfo.nih.gov/guidelines/html/1/adult-and-adolescenttreatment-guidelines/.

3. El-Serag HB, Davila JA. Surveillance for hepatocellular carcinoma: in whom and how? Therap Adv Gastroenterol 2011;4:5-10.

4. Spradling PR, Richardson JT, Buchacz K, Moorman AC, Brooks JT; HIV Outpatient Study (HOPS) Investigators. Prevalence of chronic hepatitis $B$ virus infection among patients in the HIV Outpatient Study, 1996-2007. J Viral Hepat 2010;17:879-886.

5. Aydin OA, Yemisen M, Karaosmanoglu HK, Sargin F, Gunduz A, Ceylan B, Mete B, Ozgunes N, Sevgi DY, Ozaras R, Tabak Fbak, Low Prevalence of Hepatitis C Virus Infection Among HIV-Positive Patients: Data From a Large-Scale Cohort Study in Istanbul, Turkey. Hepat Mon 2014;14:18128.

6. Hahné SJ, Veldhuijzen IK, Wiessing L, Lim TA, Salminen M, Laar Mv. Infection with hepatitis B and C virus in Europe: a systematic review of prevalence and cost-effectiveness of screening. BMC Infect Dis 2013;13:181.

7. Spradling PR, Richardson JT, Buchacz K, Moorman AC, Finelli L, Bell JT; HIV Outpatient Study Investigators. Trends in hepatitis $C$ virus infection among patients in the HIV Outpatient Study, 1996-2007. J Acquir Immune Defic Syndr 2010;53:388-396.

8. Arends JE, Lieveld FI, Boeijen LL, de Kanter CT, van Erpecum KJ, Salmon D, Hoepelman Al, Asselah T, Ustianowski A. Natural history and treatment of HCV/HIV coinfection: Is it time to change paradigms? J Hepatol 2015;63:1254-1262.

9. Yemisen M, Aydın OA, Gunduz A, Ozgunes N, Mete B, Ceylan B, Karaosmanoglu HK, Yildiz D, Sargin F, Ozaras R, Tabak F. Epidemiological profile of naive HIV-1/AIDS patients in Istanbul: the largest case series from Turkey. Curr HIV Res 2014;12:6064.

10. Dokuzoguz B, Korten $V$, Gökengin D, Fincanci $M$, Yildirmak $T$, Kes UN, Tasdelen Fisgin N, Inan D, Eraksoy $H$, Akalin $H$. Transmission route and reasons for HIV testing among recently diagnosed HIV patients in HIV-TR cohort, 2011-2012. J Int AIDS Soc 2014;17(4 Suppl 3):19595.

11. European Association For The Study Of The Liver. EASL clinical practice guidelines: Management of chronic hepatitis B virus infection. J Hepatol 2012;57:167-185.

12. Puoti M, Torti C, Bruno R, Filice G, Carosi G. Natural history of chronic hepatitis B in co-infected patients. J Hepatol 2006;44(1 Suppl):65-70.
13. Thio CL, Seaberg EC, Skolasky R Jr, Phair J, Visscher B, Muñoz A, Thomas DL; Multicenter AIDS Cohort Study. HIV-1, hepatitis $B$ virus, and risk of liver-related mortality in the Multicenter Cohort Study (MACS). Lancet 2002;360:1921-1926.

14. Nikolopoulos GK, Paraskevis D, Hatzitheodorou E, Moschidis Z, Sypsa V, Zavitsanos X, Kalapothaki V, Hatzakis A., Impact of hepatitis $B$ virus infection on the progression of AIDS and mortality in HIV-infected individuals: a cohort study and metaanalysis. Clin Infect Dis 2009;48:1763-1771.

15. Daar ESW, L.W. Contemporary Management of HIV: Managing HIV in Viral Hepatitis Coinfection. 2016 June 22, 2016]; Available from: http://www.clinicaloptions.com/HIV/Treatment.

16. Panel on Opportunistic Infections in HIV-Infected Adults and Adolescents. Guidelines for the prevention and treatment of opportunistic infections in HIV-infected adults and adolescents. December 17, 2015; Available from: https://aidsinfo.nih.gov/ contentfiles/Ivguidelines/adult_oi.pdf.

17. Graham CS, Baden LR, Yu E, Mrus JM, Carnie J, Heeren $\mathrm{T}$, Koziel MJ. Influence of human immunodeficiency virus infection on the course of hepatitis $C$ virus infection: a metaanalysis. Clin Infect Dis 2001;33:562-569.

18. Kim AY, Chung RT. Coinfection with HIV-1 and HCV--a one-two punch. Gastroenterology 2009;137:795-814.

19. Anderson JP, Tchetgen Tchetgen EJ, Lo Re V 3rd, Tate JP, Williams PL, Seage GR 3rd, Horsburgh CR, Lim JK, Goetz $M B$, Rimland $D$, Rodriguez-Barradas MC, Butt $A A$, Klein $M B$, Justice AC. Antiretroviral therapy reduces the rate of hepatic decompensation among HIV- and hepatitis C virus-coinfected veterans. Clin Infect Dis 2014;58:719-727.

20. Lo Re V, Kallan MJ, Tate JP, Localio AR, Lim JK, Goetz MB, Klein $M B$, Rimland $D$, Rodriguez-Barradas $M C$, Butt $A A$, Gibert $C L$, Brown ST, Park L, Dubrow R, Reddy KR, Kostman JR, Strom $B L$, Justice AC. Hepatic decompensation in antiretroviral-treated patients co-infected with HIV and hepatitis C virus compared with hepatitis C virus-monoinfected patients: a cohort study. Ann Intern Med 2014;160:369-379.

21. AASLD-IDSA. Hepatitis C guidance: AASLD-IDSA recommendations for testing, managing, and treating adults infected with hepatitis C virus. Hepatology 2015;62:932-954.

22. Chen JY, Feeney ER, Chung RT. HCV and HIV co-infection: mechanisms and management. Nat Rev Gastroenterol Hepatol 2014;11:362-371.

23. Shire NJ, Welge JA, Sherman KE. Response rates to pegylated interferon and ribavirin in HCV/HIV coinfection: a research synthesis. J Viral Hepat 2007;4:239-248.

24. Hepatitis $C$ online.Treatment of Hepatitis $C$ in Patients with HIV Coinfection. June 22, 2016; Available from: http://www. hepatitisc.uw.edu/pdf/special-populations-situations/treatmenthiv-coinfection.

25. Saeed S, Strumpf EC, Walmsley SL, Rollet-Kurhajec K, Pick $\mathrm{N}$, Martel-Laferrière $\mathrm{V}$, Hull M, Gill MJ, Cox J, Cooper C, Klein MB; Canadian Co-Infection Cohort Study. How Generalizable Are the Results From Trials of Direct Antiviral Agents to People Coinfected With HIV/HCV in the Real World? Clin Infect Dis 2016;62:919-926.

26. Lakshmi S, Alcaide M, Palacio AM, Shaikhomer M, Alexander AL, Gill-Wiehl G, Pandey A, Patel K, Jayaweera D, Del Pilar Hernandez M. Improving HCV cure rates in HIV-coinfected patients - a real-world perspective. Am J Manag Care 2016;22:198-204.

27. Resmi Gazete. Sosyal Güvenlik Kurumu Sağlık Uygulama Tebliğinde Değişiklik Yapılmasına Dair Tebliğ. 2016 June 18, 2016; Available from: http://www.resmigazete.gov.tr/. 